\title{
Corrigendum: Work-family enrichment and psychological health
}

\author{
Authors: \\ Ameeta Jaga ${ }^{1}$ \\ Jeffrey Bagraim ${ }^{1}$ \\ Zahira Williams ${ }^{1}$

\section{Affiliations:} \\ ${ }^{1}$ Department of \\ Organisational Psychology, \\ University of Cape Town, \\ South Africa \\ Correspondence to: \\ Ameeta Jaga \\ Email: \\ ameeta.jaga@uct.ac.za \\ Postal address: \\ Private Bag X3, Rondebosch \\ 7701, South Africa \\ Dates: \\ Published: 30 Sept. 2013 \\ How to cite this article: \\ Jaga, A., Bagraim, J., \\ \& Williams, Z. (2013). \\ Corrigendum: Work- \\ family enrichment and \\ psychological health. \\ SA Journal of Industrial \\ Psychology/SA Tydskrif vir \\ Bedryfsielkunde, 39(2), \\ Art. \#1143, 10 pages. \\ http://dx.doi.org/10.4102/ \\ sajip.v39i2.1143-1 \\ Note: \\ Doi of original article: \\ http://dx.doi.org/10.4102/ \\ sajip.v39i2.1143

\section{Copyright:} \\ (C) 2013. The Authors. \\ Licensee: AOSIS \\ OpenJournals. This work \\ is licensed under the \\ Creative Commons \\ Attribution License. \\ Read online:

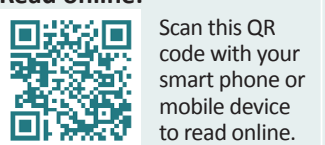

In the abstract on page 1 'Research approach, design and method', the sentence 'Employees in two national organisations in the financial retail and logistics industries completed a selfadministered survey questionnaire' must read 'Employees in two national organisations in the retail and logistics industries completed a self-administered survey questionnaire.'

On the bottom of page 4 under the heading 'Research participants' the sentence 'Authors conducted the study in two national organisations: the financial division of a retail organisation and a logistics company', must read 'Authors conducted the study in two national organisations: a division of a retail organisation and a logistics company. 